\title{
Fullfunksjonsvilkårets konkurranserettslige implikasjoner og virkefelt
}

\section{Sammendrag}

Fullfunksjonsvilkåret i felleseuropeisk og norsk konkurranserett fremkommer av legaldefinisjonen av foretakssammenslutningsbegrepet. Det følger derav at også opprettelser av selvstendig fungerende (fullfunksjons) fellesforetak kvalifiserer som foretakssammenslutninger. I artikkelen systematiseres fullfunksjonsvilkårets implikasjoner for reglene om både foretakssammenslutninger og konkurranseskadelig atferd. På den bakgrunn drøftes vilkårets virkefelt og forhold til foretaksfusjoner og kontrollovertakelser av foretak. Tematikken er aktualisert av tolkningsavgjørelse 7. september 2017 i saken Austria Asphalt vs. Bundeskartellanwalt. EU-domstolen uttalte her at en endring fra enekontroll til felleskontroll over et foretak kun utgjør en foretakssammenslutning såfremt fellesforetaket som oppstår, ivaretar en fullfungerende virksomhets funksjoner. I artikkelen underbygges at EU-domstolens formuleringer kan risikere at konkurranseskadelige foretaksstrukturendringer verken kan hindres av konkurranserettens foretakssammenslutningsregler eller atferdsregler. Det argumenteres videre for en restriktiv fortolkning av fullfunksjonsvilkårets virkeområde.

\section{Innhold}

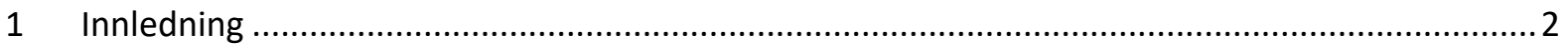

2 Fullfunksjonsvilkårets foretakssammenslutningsrettslige implikasjoner .....................................

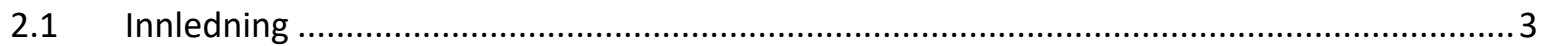

2.2 Foretakssammenslutningsbegrepet vs. fullfunksjonsvilkåret.............................................

2.3 Foretakssammenslutningsreglene vs. fullfunksjonsvilkåret ................................................ 4

3 Fullfunksjonsvilkårets atferdsrettslige implikasjoner .................................................................

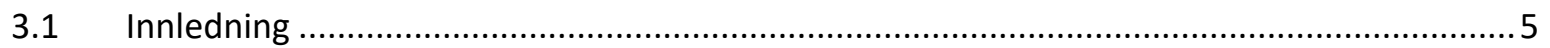

3.2 Atferdsrettslig håndhevingskompetanse vs. fullfunksjonsvilkåret ...................................... 6

3.3 Atferdsforbudsreglene vs. fullfunksjonsvilkåret ................................................................. 7

4 Fullfunksjonsvilkårets virkefelt vs. foretaksfusjoner og kontrollovertakelser ............................... 9

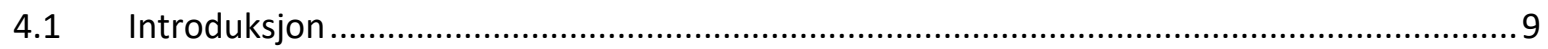

4.2 EU-domstolen i Austria Asphalt vs. Bundeskartellanwalt.................................................... 10

4.3 Fullfunksjonsvilkårets virkefelt etter Austria Asphalt vs. Bundeskartellanwalt ...................12 


\section{Innledning}

Temaet her er fullfunksjonsvilkårets implikasjoner og virkefelt i felleseuropeisk og norsk konkurranserett.

Fullfunksjonsvilkåret fremgår av foretakssammenslutningsdefinisjonen i EUs fusjonsforordning ${ }^{1}$ artikkel 3 og konkurranseloven ${ }^{2} \S 17 .^{3}$ Foretakssammenslutningsbegrepet omfatter opprettelser av fullfungerende fellesforetak, foruten foretaksfusjoner og foretaks kontrollovertakelser av foretak. Fullfunksjonsvilkåret stiller krav til foretakets operasjonelle autonomi, noe som innebærer at det må etableres med tilsvarende funksjoner som en selvstendig økonomisk virksomhet.

Foretakssammenslutningsbegrepet er et konkurranserettslig koblingsord. Ikke bare angir det gjenstanden for reglene om forhåndskontroll med foretaksstrukturelle endringer. ${ }^{4}$ Begrepet utgjør også en skranke for konkurransemyndighetenes håndhevingskompetanse vedrørende atferdsforbudene mot konkurranseskadelig samordning ${ }^{5}$ og misbruk av markedsdominans. ${ }^{6}$

Fullfunksjonsvilkårets virkefelt betegner forholdet til foretaksfusjoner og foretaks kontrollovertakelser av andre foretak. Det er lite kontroversielt at fellesforetak som ikke kommer i stand ved fusjon eller kontrollendring over eksisterende foretak, må opprettes til å bli fullfungerende for å utgjøre en foretakssammenslutning. Mer diskutabelt er spørsmålet om fullfunksjonskravet eksempelvis også gjelder fellesforetak som kommer i stand ved fusjon eller kontrollendring. Virkefeltet påvirker foretakssammenslutningsbegrepets rekkevidde og har implikasjoner for samvirket mellom reglene om forhåndskontroll av foretakssammenslutninger og etterhåndskontroll med atferd.

Tematikken er aktualisert av EU-domstolens tolkningsavgjørelse i Austria Asphalt vs. Bundeskartellanwalt ${ }^{7}$ av 7. september 2017, der domstolen for første gang tok stilling til fullfunksjonsvilkårets virkefelt. Spørsmålet fra $\emptyset$ sterrikes Oberster Gerichtshof var om en endring fra enekontroll til felleskontroll over et foretak, der det enekontrollerende foretaket blir et felleskontrollerende foretak, kun utgjør en foretakssammenslutning («concentration») der foretaket varig ivaretar funksjonene til en fullfungerende virksomhet. EU-domstolen svarte bekreftende. I slutningen heter det at "a concentration is deemed to arise upon a change in the form of control of an existing undertaking which, previously exclusive, becomes joint, only if the joint venture created by such a transaction performs on a lasting basis all the functions of an autonomous economic entity". Formuleringen anviser at fullfunksjonsvilkåret også gjelder (enkelte) foretaksfusjoner og kontrollovertakelser av foretak. For $\varnothing$ vrig er avgjørelsen kortfattet, og EU-domstolens kildebruk og grunngiving er systemorientert.

\footnotetext{
${ }^{1}$ Reg. 139/2004 on the control of concentrations between undertakings (the EC Merger Regulation), heretter "fusjonsforordningen».

${ }^{2}$ Lov 5. mars 2004 nr. 12 om konkurranse mellom foretak og kontroll med foretakssammenslutninger (konkurranseloven).

${ }^{3}$ Konkurranselovens foretakssammenslutningsbegrep er ment å tilsvare EU/E $\varnothing S$-fusjonsrettens "concentration», se Ot.prp. nr. 6 (2003-2004) om lov om konkurranse mellom foretak og kontroll med foretakssammenslutninger (konkurranseloven), s. 231.

4 Jf. fusjonsforordningen og konkurranseloven kapittel 4.

${ }^{5}$ TEUV artikkel 101, EØS artikkel 53, konkurranseloven § 10.

${ }^{6}$ TEUV artikkel 102, EØS artikkel 54, konkurranseloven $\S 11$.

${ }^{7}$ Sak C-248/16, Austria Asphalt, ECLI:EU:C:2017:643.
} 
Siktemålet i det følgende er å systematisere fullfunksjonsvilkårets foretakssammenslutningsrettslige og atferdsrettslige implikasjoner (del 2 og 3). På den bakgrunn diskuteres vilkårets virkefelt og avgjørelsen i Austria Asphalt vs. Bundeskartellanwalt (del 4). Konsistent med EU-domstolens systemrettede tolkningsavgjørelse, vil artikkelen blant annet drøfte om en ved en ekspansiv tolkning av fullfunksjonskravets virkefelt risikerer at konkurranseskadelige foretaksstrukturendringer verken kan hindres av foretakssammenslutnings- eller atferdsregelverkene.

\section{Fullfunksjonsvilkårets foretakssammenslutningsrettslige implikasjoner}

\section{$2.1 \quad$ Innledning}

Fullfunksjonsvilkåret har både direkte og indirekte foretakssammenslutningsrettslige implikasjoner. Direkte innvirker fullfunksjonsvilkåret på foretakssammenslutningsbegrepets innhold og rekkevidde. Gjennom foretakssammenslutningsbegrepet har vilkåret indirekte betydning for $\emptyset$ vrige foretakssammenslutningsregler.

\subsection{Foretakssammenslutningsbegrepet vs. fullfunksjonsvilkåret}

Etter fusjonsforordningen artikkel 3 (1) og konkurranseloven $\S 17$ første ledd foreligger en foretakssammenslutning når (a) uavhengige foretak fusjonerer, eller (b) ett eller flere foretak, direkte eller indirekte, helt eller delvis, varig overtar kontrollen over ett eller flere andre foretak. Foretaksfusjoner kan komme i stand ved nystiftelse og opptak. ${ }^{8}$ Kontrollerverv oppnås gjennom rettigheter, avtaler eller andre midler som gir mulighet til å utøve avgjørende innflytelse over et foretaks virksomhet. ${ }^{9}$ Det følger videre av fusjonsforordningen artikkel 3 (4) og konkurranseloven § 17 annet ledd at også opprettelsen av et selvstendig fungerende fellesforetak utgjør en foretakssammenslutning. Foretakssammenslutningsbegrepet omfatter følgelig varige foretaksstrukturendringer i form av foretaksfusjoner, kontrollerverv av foretak og opprettelser av fullfungerende fellesforetak.

Foretakssammenslutningsbegrepet er forbundet med konkurranserettens foretaksbegrep. Foretaksbegrepet er konkurranserettslig autonomt, funksjonelt, aktivitetsrelativt og ikke knyttet til særskilte juridiske personer. ${ }^{10}$ Det avgjørende er ut $\varnothing v e l s e$ av $\varnothing$ konomisk virksomhet, ${ }^{11}$ det vil si tilbud av varer eller tjenester $i$ et marked. ${ }^{12}$ Foretak avgrenses som $\emptyset$ konomiske enheter som kan bestå av flere juridiske og fysiske personer. ${ }^{13}$ Avgrensningen beror på om en $\emptyset$ konomisk virksomhet er underlagt en annens avgjørende innflytelsesmulighet (kontroll), eller om virksomhetene er strategisk autonome. ${ }^{14}$ En foretakssammenslutning er en konsolidering av selvstendige foretak, slik at det ikke lenger er tale om strategisk autonome $\varnothing$ konomiske enheter. ${ }^{15}$

Fullfungerende fellesforetaksetableringer utgjør også foretakssammenslutninger. Begrepet «fellesforetak» / «joint venture» er ikke legaldefinert. Foretaket som opprettes må underlegges felles kontroll. I tillegg må fellesforetaket opprettes til en varig fullfungerende virksomhet for å utgjøre en

\footnotetext{
8 Jurisdiksjonsmeddelelsen, avsnitt 9.

${ }^{9}$ Fusjonsforordningen artikkel 3 (2) og konkurranseloven $\S 17$ tredje ledd.

${ }^{10}$ Konkurranseloven $\S 2$.

${ }^{11}$ Sak C-41/90, Höfner, ECLI:EU:C:1991:161, avsnitt 21 og konkurranseloven $§ 2$.

12 Sak C-205/03, FENIN, ECLI:EU:C:2006:453, avsnitt 25.

${ }^{13}$ Sak 170/83, Hydrotherm, ECLI:EU:C:1984:271, avsnitt 11.

${ }^{14}$ Sak C-73/95, Viho Europe, ECLI:EU:C:1996:405, avsnitt 16.

${ }^{15}$ Sak T-411/07, Aer Lingus, ECLI:EU:T:2010:281, avsnitt 63.
} 
foretakssammenslutning. Felleskontroll- og fullfunksjonsvilkåret angår ulike aspekter ved fellesforetakets autonomi. Kravet til felles kontroll innebærer at fellesforetaket ikke kan være strategisk autonomt, mens fullfunksjonsvilkåret innebærer at fellesforetaket må være operasjonelt autonomt. ${ }^{16}$

Kravet til operasjonell autonomi tilsier at fellesforetaket må ha tilsvarende indre og ytre funksjoner som en selvstendig virksomhet. ${ }^{17}$ For å ha nødvendige indre funksjoner anser EU-kommisjonen at fellesforetaket må ha en ledelse med ansvar for foretakets daglige aktiviteter, samt tilgang til tilstrekkelige ressurser, herunder finansielle midler, personale, materielle og immaterielle aktiva, for å kunne ut $\varnothing v e$ $\varnothing$ konomisk virksomhet. ${ }^{18}$ Når det gjelder fellesforetakets ytre funksjoner, har EUkommisjonen blant annet uttrykt at fellesforetaket må ha tilstrekkelig selvstendig markedstilstedeværelse og ikke bare utføre en foretaksintern oppgave eller ha kjøp- eller salgsrelasjoner til de felleskontrollerende foretakene. ${ }^{19}$

Foretakssammenslutningsbegrepets rekkevidde beror også på fullfunksjonskravets virkefelt. Dersom fullfunksjonsvilkåret også gjelder ved (enkelte) foretaksfusjoner og kontrollerverv, innsnevres foretakssammenslutningsbegrepet. Alternativet er at bestemmelsen om fullfungerende fellesforetak kun utvider begrepet til fellesforetaksetableringer som ikke er dekket av fusjons- eller kontrollervervsbestemmelsene. ${ }^{20}$

\subsection{Foretakssammenslutningsreglene vs. fullfunksjonsvilkåret}

Foretakssammenslutningsbegrepet angir gjenstanden for den felleseuropeiske konkurranserettens og konkurranselovens forhåndskontrollregelverk. Gjennom dette begrepet innvirker fullfunksjonsvilkårets virkefelt på øvrige foretakssammenslutningsregler.

En eventuell meldeplikt til EU-kommisjonen ${ }^{21}$ eller Konkurransetilsynet ${ }^{22}$ beror blant annet på foretakssammenslutningsbegrepet. ${ }^{23}$ Fullfunksjonskravets virkefelt innvirker således indirekte på meldepliktens kvalitative rekkevidde. Kvantitativt fastlegges jurisdiksjon og meldeplikt av fusjonsforordningens og konkurranselovens regler om omsetningsterskler og omsetningsberegning. ${ }^{24}$

Innholdskravene til meldinger har også sider til foretakssammenslutningsbegrepet og fullfunksjonskravets virkefelt. Blant annet følger at ved opprettelser av fullfungerende fellesforetak skal meldingen opplyse om de kontrollerende foretakene fortsatt vil være virksomme på samme eller

\footnotetext{
${ }^{16}$ Sak T-282/02, Cementbouw, ECLI:EU:T:2006:64, avsnitt 62 og sak C-179/12, Dow, ECLI:EU:C:2013:605, avsnitt 65. Se også Jurisdiksjonsmeddelelsen, avsnitt 93.

${ }^{17}$ Om fullfunksjonsvilkårets meningsinnhold, se bl.a. Anders Ryssdal og Håkon Cosma Størdal, Norsk Konkurranserett, Bind II - Fusjonskontroll, Universitetsforlaget 2018, s. 62 flg. og Lene Sommerfelt, Fullfunksjonskriteriet i konkurranseloven $\S 17$ annet ledd, Masteroppgave UiO, 2016, tilgjengelig www.duo.uio.no. Om joint ventures i konkurranseretten, se Anders Ryssdal, Joint Ventures - en konkurranserettslig analyse, Universitetsforlaget 2003.

18 Jurisdiksjonsmeddelelsen, avsnitt 94.

19 Jurisdiksjonsmeddelelsen, avsnitt 95-102.

${ }^{20}$ Se del 4.

${ }^{21} \mathrm{Jf}$. fusjonsforordningen artikkel 4.

22 jf. konkurranseloven $\S 18$.

${ }^{23}$ Konkurransetilsynet har også kompetanse til å pålegge meldeplikt for foretakserverv av ikke-kontrollerende andeler i foretak, jf. konkurranseloven $\S 18$ femte ledd.

${ }^{24}$ Fusjonsforordningen artikkel 1 og 5 og konkurranseloven $\S 18$ annet ledd og Forskrift 11. desember $2013 \mathrm{nr}$. 1466 om melding av foretakssammenslutninger mv. (meldingsforskriften) $\S 5$.
} 
et tilknyttet marked som fellesforetaket. ${ }^{25}$ En ekspansiv tolkning av fullfunksjonsvilkårets virkefelt til også å gjelde (enkelte) foretaksfusjoner eller kontrollovertakelser vil utvide opplysningskravets virkeområde tilsvarende.

Gjennomføringsforbudene ${ }^{26} \quad$ påvirkes videre av fullfunksjonskravet. Foretakssammenslutningsbegrepet ligger til grunn for tolkningen og anvendelsen av forbudene mot gjennomføring av meldepliktige foretakssammenslutninger uten myndighetsklarering. Forbudene rammer implementering av en foretakssammenslutning ved etableringen av en ny $\varnothing$ konomisk enhet, men ikke atferdsmessige forberedelseshandlinger. ${ }^{27}$ For foretakssammenslutninger uten fullfunksjonskrav kan gjennomføringsforbudet overtres ved kontrollovertakelse av et annet foretak. For foretaksstrukturendringer der fullfunksjonsvilkåret eventuelt gjelder, vil gjennomføringsforbudet ikke overtres $f \varnothing r$ foretaket blir fullfungerende. ${ }^{28}$

Fullfunksjonskravet har dessuten innvirkning på konkurransemyndighetenes inngrepskompetanse. Foretakssammenslutningsbegrepet angir gjenstanden for EU-kommisjonens og Konkurransetilsynets kompetanse til å gripe inn mot konkurranseskadelige foretaksstrukturendringer. ${ }^{29}$ En ekspansiv fortolkning av fullfunksjonsvilkårets virkefelt begrenser myndighetenes inngrepskompetanse. Et eksempel kan være en felleskontrolletablering over et foretak som ikke vil settes opp med nødvendige indre ressurser og funksjoner og derfor ikke vil bli fullfungerende. Selv om fellesforetaket og et (felles-)kontrollervervende foretak har overlappende virksomhet og foretaksstrukturendringen skulle lede til et markedsstrukturelt monopol, vil konkurransemyndighetene ikke ha inngrepskompetanse dersom det ikke er tale om en foretakssammenslutning. Et annet eksempel kan være en felleskontrolletablering over et foretak som kun skal tilby produksjonen til det (felles-)kontrollovertakende foretaket og dermed vil miste $n \varnothing$ dvendig ytre operasjonell autonomi til å kvalifisere som fullfungerende. Selv om foretaksstrukturendringen skulle medføre at det felleskontrollerende foretaket oppnår en monopolstilling, ved at konkurrenter ikke lenger vil få tilgang til nødvendige innsatsfaktorer fra fellesforetaket, vil et fullfunksjonskrav avskjære inngrepskompetansen også her.

\section{$3 \quad$ Fullfunksjonsvilkårets atferdsrettslige implikasjoner}

\subsection{Innledning}

Fullfunksjonsvilkåret har også implikasjoner for håndhevingen og anvendelsen av forbudene mot konkurransebegrensende samarbeid ${ }^{30}$ og misbruk av markedsdominans. ${ }^{31}$ Myndighetenes håndhevingskompetanse begrenses av foretakssammenslutningsbegrepet. En ekspansiv fortolkning av fullfunksjonsvilkårets virkefelt innsnevrer foretakssammenslutningsbegrepet og utvider

\footnotetext{
${ }^{25}$ Form CO section 10, inntatt i Reg. 802/2004 implementing Reg. 139/2004 on the control of concentrations between undertakings. I konkurranseloven $\S 18$ a annet ledd benyttes termene "opprettelse av fellesforetak» som tilsvarer terminologien i konkurranseloven $\S 17$ annet ledd om fullfungerende fellesforetak.

${ }^{26} \mathrm{Jf}$. fusjonsforordningen artikkel 7 og konkurranseloven $\S 19$.

27 Sak C-84/13, Electrabel, ECLI:EU:C:2014:2040, sak T-704/14, Marine Harvest, ECLI:EU:T:2017:753, sak C633/16, Ernst \& Young, ECLI:EU:C:2018:371. Sml. Konkurransetilsynets avgjørelse A2018-1, Fabritius Gruppen A Bygg Gruppen og V2018-22 - Sector Alarm/Sector Alarm Group - Nokas.

${ }^{28}$ I den retning også Jurisdiksjonsmeddelelsen, avsnitt 105. Tilsvarende for fusjonsforordningen artikkel 4 (1).

${ }^{29}$ Jf. fusjonsforordningen artikkel 2 og konkurranseloven $\S 16$. Se likevel konkurranseloven $\S 16$ a.

30 TEUV artikkel 101, EØS artikkel 53, konkurranseloven $\S 10$.

${ }^{31}$ TEUV artikkel 101, EØS artikkel 53, konkurranseloven $\S 10$.
} 
myndighetenes atferdsrettslige håndhevingskompetanse tilsvarende. De materielle atferdsforbudsvilkårene kan likevel hindre effektiv håndheving av konkurranseskadelige foretaksstrukturendringer.

\subsection{Atferdsrettslig håndhevingskompetanse vs. fullfunksjonsvilkåret}

Med forordning 4064/89 mistet EU-kommisjonen kompetanse til å håndheve atferdsforbudsreglene på foretakssammenslutninger. ${ }^{32}$ Kompetansebegrensningen ble videreført ved fusjonsforordningen $139 / 2004$ og forordning $1 / 2003 .{ }^{33}$ Det følger av fusjonsforordningen 139/2004 artikkel 21 (1) at "[t]his Regulation alone shall apply to concentrations as defined in Article 3, and Council Regulations (EC) No 1/2003 (...) shall not apply (...)». ESA er tilsvarende forhindret fra å håndheve EØS-avtalens atferdsforbud på foretakssammenslutninger ved at ODA ${ }^{34}$ Protokoll 4 inntar tilsvarende regler. Heller ikke medlemsstatenes konkurransemyndigheter har kompetanse etter forordning 1/2003 til å håndheve traktatens atferdsforbudsregler på slike foretaksstrukturendringer. ${ }^{35}$ Konkurransetilsynets kompetanse til å håndheve $E \varnothing S$ artikkel 53 og 54 på foretakssammenslutninger er tilsvarende avgrenset. ${ }^{36}$

Konkurransetilsynets kompetanse til å anvende konkurranseloven $\S \S \quad 10 \quad$ og 11 på foretakssammenslutninger er ikke uttrykkelig lovregulert, har ikke vært domstolsbehandlet og er ikke omhandlet i lovforarbeidene. Når det gjelder foretakssammenslutninger som omfattes av fusjonsforordningen, har EU-kommisjonen alene myndighet. ${ }^{37}$ Der Konkurransetilsynet har henlagt en meldt foretakssammenslutning, er tilsynet i utgangspunktet forhindret fra senere inngrep under foretakssammenslutningsreglene. Det samme er tilfellet der tilsynet ikke har overholdt saksbehandlingsfrister. ${ }^{38}$ Avklaringshensyn tilsier at tilsynet da også er forhindret fra å anvende atferdsforbudsreglene. Når det gjelder foretakssammenslutninger som er unntatt fra generell meldeplikt, ${ }^{39}$ kan tilsynet innen en tremånedersfrist undertiden pålegge melding. ${ }^{40}$ Der fristen er overskredet, har tilsynet heller ikke inngrepskompetanse. ${ }^{41}$ Hensyn til forutberegnelighet og avklaring tilsier også her at tilsynet er forhindret fra å anvende atferdsforbudsreglene. Ulovfestede alminnelige forvaltningsrettslige regler gir Konkurransetilsynet en begrenset endrings- og inngrepskompetanse mot tillatt gjennomførte foretakssammenslutninger etter en interesseavveining. En videre adgang til å anvende atferdsforbudsreglene på foretakssammenslutninger enn den forvaltningsrettslige endringsadgangen tilsier, er det neppe grunnlag eller behov for. For $\varnothing$ vrig er det vanskelig å se at

\footnotetext{
${ }^{32} \mathrm{~F} \varnothing \mathrm{r}$ forordning 4064/89 anvendte EU-kommisjonen undertiden atferdsforbudene på fusjoner og oppkjøp etter håndhevingsreglene i forordning 17/62, se sak 6/72, Continental Can, ECLI:EU:C:1973:22.

${ }^{33}$ Fusjonsforordningens fortale, avsnitt 6.

${ }^{34}$ Avtale mellom EFTA-statene om opprettelse av et Overvåkingsorgan og en Domstol (ODA).

${ }^{35}$ Se også sak C-248/16, Austria Asphalt mot Bundeskartellanwalt, ECLI:EU:C:2017:643, avsnitt 33.

${ }^{36}$ ODA Protokoll 4 og lov 5. mars 2004 nr. 11 om gjennomføring av EØS-avtalens konkurranseregler mv. (EØSkonkurranseloven), §6.

37 Jf. EØS-avtalen artikkel 57.

38 Jf. konkurranseloven § 20. Se for $\varnothing$ vrig departementets klagevedtak 24. mai 2005 vedrørende V2005-3, Swarco Norge - Peek Trafikk.

${ }^{39}$ Konkurranseloven $§ 18$ annet ledd.

$40 \mathrm{Jf}$. konkurranseloven $\S 18$ tredje ledd.

${ }^{41}$ Med mindre det foreligger omgjøringsadgang, jf. forvaltningsloven § 35 .
} 
Konkurransetilsynet burde ha en videre atferdsrettslig håndhevingskompetanse enn EUkommisjonen, og tilsynet har da heller aldri anvendt atferdsreglene på foretakssammenslutninger. ${ }^{42}$

Atferdsforbudene kan også håndheves privatrettslig. Norske domstoler kan i utgangspunktet anvende $E \emptyset \mathrm{S}$-avtalens og konkurranselovens atferdsforbud på foretakssammenslutninger som faller utenfor fusjonsforordningens anvendelsesområde. For klarerte og tillatt gjennomførte foretakssammenslutninger tilsier likevel avklaringshensyn at domstolene utviser tilbakeholdenhet.

Foretakssammenslutningsbegrepet begrenser følgelig myndighetenes kompetanse til å håndheve forbudene mot konkurransebegrensende samarbeid og misbruk av dominans. Fullfunksjonskravets virkefelt innvirker derved på håndhevingskompetansen. Dersom fullfunksjonsvilkåret skulle innsnevre foretakssammenslutningsbegrepet, vil konkurransemyndighetenes atferdsrettslige håndhevingskompetanse utvides tilsvarende. ${ }^{43}$ De materielle forbudsvilkårene bør da kunne adressere eventuelle konkurranseproblemer som slike foretaksstrukturendringer skulle medføre.

\subsection{Atferdsforbudsreglene vs. fullfunksjonsvilkåret}

Forbudet mot misbruk av markedsdominans kommer ikke til anvendelse på ikke-dominerende foretaks markedsopptreden. En dominerende markedsposisjon som forsterkes av en foretaksstrukturendring, kan riktignok utgjøre en overtredelse. ${ }^{44}$ Men foretaksstrukturendringer som skaper en dominerende markedsposisjon, vil ikke være i strid med forbudet. Forbudet kan følgelig ikke anvendes på enhver konkurranseskadelig foretaksstrukturendring som ikke omfattes av foretakssammenslutningsreglene.

Forbudet mot konkurransebegrensende samarbeid krever kvalifisert koordinering ${ }^{45}$ mellom selvstendige foretak. Konkurranseskadelige foretaksstrukturendringer kan imidlertid komme i stand uten slik koordinering. Eksempler er passive kontrollendringer ${ }^{46}$ og erverv av foretaksandeler fra fysiske personer eller ved børshandel. Foretakstransaksjoner mellom ervervende og avhendende foretak oppfyller heller ikke nødvendigvis koordineringskravet. ${ }^{47}$

Dessuten er ikke forbudet mot konkurransebegrensende samarbeid anvendelig på koordinering mellom juridiske personer som inngår i samme økonomiske enhet (samme «foretak»), for eksempel mellom mor- og datterselskap. ${ }^{48}$ Etterfølgende koordinering mellom virksomheter som har etablert en $\varnothing$ konomisk enhet ved en foretaksstrukturendring, vil derfor heller ikke omfattes av forbudet.

$\varnothing$ konomiske enheter avgrenses av kontrollvurderinger. Et foretaks ikke-kontrollerende andeler $\mathrm{i}$ et annet foretak vil ikke være tilstrekkelig. ${ }^{49}$ Erverv av slike andeler utgjør da heller ingen

\footnotetext{
42 Konkurransetilsynet har endog uttalt at tilsynet ikke har mulighet til å reversere en eventuell strukturell skade som følge av uriktig foretakssammenslutningsklarering, jf. Konkurransetilsynets vedtak V2014-13, Nortura - Prima Slakt / NorPri / Jæren Eiendomsinvest, avsnitt 145 og V2016-5, Sogn og Fjordane fylkeskommune - Torghatten, avsnitt 392.

${ }^{43}$ For et liknende, men motsatt resonnement, se sak C-633/16, Ernst \& Young, ECLI:EU:C:2018:371, avsnitt 5558.

${ }^{44}$ Sak 6/72, Continental Can, ECLI:EU:C:1973:22.

45 I form av «avtale», «samordnet opptreden» eller «beslutning av sammenslutninger av foretak».

${ }^{46}$ Se Jurisdiksjonsmeddelelsen, avsnitt 21.

${ }^{47}$ Om koordineringskravet, se bl.a. sak C-194/14, AC-Treuhand, ECLI:EU:C:2015:717, avsnitt 30.

48 Sak 48/69, ICI, ECLI:EU:C:1972:70, avsnitt 134.

${ }^{49}$ Sak T-141/89, Tréfileurope, ECLI:EU:T:1995:62, avsnitt 129.
} 
foretakssammenslutning. En foretaksrelasjon i form av positiv kontroll vil derimot utgjøre en $\varnothing$ konomisk enhet. ${ }^{50}$ Positiv kontroll betegner et foretaks mulighet til å fastlegge en virksomhets markedsstrategi.

Når det gjelder negativ enekontroll og felleskontroll, er det ikke rettsavgjørelser fra EU-domstolen eller norske domstoler som direkte drøfter om kontrollformene etablerer $\varnothing$ konomiske enheter ved anvendelsen av de materielle atferdsreglene. Negativ kontroll viser til et foretaks mulighet til å blokkere avgjørende strategiske virksomhetsbeslutninger. Felles kontroll innebærer at to eller flere foretak har negativ kontroll over en virksomhet. ${ }^{51}$

Dersom det foreligger en kontrollrelasjon, enten den er av positiv eller negativ karakter, kan uavhengig markedsopptreden og konkurranse mellom den kontrollerende og den kontrollerte virksomheten ikke

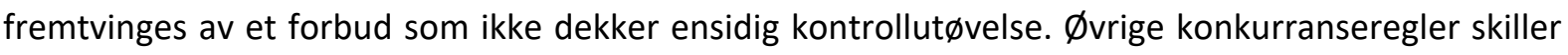
da heller ikke mellom positiv enekontroll, negativ enekontroll og felleskontroll. Foretakssammenslutningsbegrepet omfatter alle kontrollformene. ${ }^{52}$ Det samme er tilfellet for reglene om omsetningsberegning for fastlegging av jurisdiksjon og meldeplikt. ${ }^{53}$ Reglene om gjennomføringsforbud, meldingskrav og inngrep gjelder også samtlige kontrollformer. Under atferdsregelverkene omfattes også kontrollformene negativ enekontroll og felles kontroll av gruppefritakenes foretaksavgrensningsregler. ${ }^{54}$ I tillegg omfatter foretaksbegrepet som ligger til grunn for reglene om ansvarsplassering og utmåling av sivilrettslige bøter, alle kontrollformer. ${ }^{55}$

Ulik foretaksavgrensning under konkurranseregelverkets ulike deler ville dessuten gitt inkonsekvente utslag. For eksempel gir det liten mening at en negativt kontrollerende eller felleskontrollerende produsent og en kontrollert distribut ør utgjør ett foretak etter gruppefritaket for vertikale avtaler, dersom distribusjonsordningen skulle anses å foreligge mellom separate foretak etter forbudet. Ulike kontrollformskrav under foretakssammenslutningsbegrepet, atferdsforbudenes materielle foretaksbegrep og foretaksbegrepet for sivilrettslige bøteansvar ville gitt enda mer paradoksale utslag. Et eksempel kan være et foretakserverv ved negativ kontroll som oppnår forhåndsgodkjenning etter foretakssammenslutningsreglene. Forhåndsgodkjenningen gir begrenset avklaring dersom virksomhetene likevel anses som separate foretak under atferdsforbudsreglene. Koordinering mellom kontrollerende og kontrollert virksomhet ville da kunne anses som kartellvirksomhet. ${ }^{56}$ Selv etterlevelsestiltak overfor kontrollerte virksomheter ville potensielt utgjøre ulovlig samordning. Når den sivilrettslige boten skulle ilegges og utmåles, ville overtrederne dessuten anses som én og samme

\footnotetext{
50 Sak C-73/95, Viho Europe, ECLI:EU:C:1996:405.

${ }^{51}$ Sak T-282/02, Cementbouw, ECLI:EU:T:2006:64, avsnitt 42.

${ }^{52}$ Fusjonsforordningen artikkel 3 og konkurranseloven $\S 17$.

${ }^{53}$ Fusjonsforordningen artikkel 5 og meldingsforskriften $\S 5$.

${ }^{54}$ Se til eksempel regulation 330/2010 on the application of Article 101(3) of the Treaty on the Functioning of the European Union to categories of vertical agreements and concerted practice, artikkel 1 (2).

${ }^{55}$ EU-kommisjonens praksis har gjennomgått en viss utvikling (se COMP/F/38.443, Rubber Chemicals (2005), COMP/E-1/36.765, Sodium Gluconate og sak T-314/01, Avebe, ECLI:EU:T:2006:266, COMP/F/38.899, Gas Insulated Switchgear og sak T-132/07, Fuji, ECLI:EU:T:2011:344, COMP/39181, Candle Waxes). EU-domstolen har i senere tid stadfestet EU-kommisjonens adgang til å holde felleskontrollerende og negativt enekontrollerende juridiske personer ansvarlige også for fullfungerende fellesforetaks markedsatferd. (Se sak C-172/12, du Pont, ECLI:EU:C:2013:601 og sak C-179/12, Dow, ECLI:EU:C:2013:605.)

${ }^{56}$ Men ikke ensidig kontrollutøvelse.
} 
$\varnothing$ konomisk enhet. At ett enkelt foretak skulle være ansvarlig for en materiell overtredelse som krever samordning mellom flere foretak, ville vært en vanskelig operasjonaliserbar ansvarskonstruksjon.

Det kan nevnes at EU-kommisjonens behandling av negativ/felles kontroll under det materielle foretaksbegrepet historisk har fremstått vilkårlig eller under utvikling. ${ }^{57}$ Senere praksis om bøteansvar for felleskontrollerende foretak samsvarer likevel med fraværet av senere overtredelsesvedtak om koordinering mellom kontrollerende og kontrollerte juridiske personer.

De materielle atferdsforbudsreglene kan etter dette vanskelig fullgodt motvirke konkurranseskadelige foretaksstrukturendringer som eventuelt faller utenfor foretakssammenslutningsbegrepet. En ekspansiv fortolkning av fullfunksjonskravets virkefelt innskrenker foretakssammenslutningsbegrepet. Det risikerer å skape en konkurranserettslig «blindsone» der konkurranseskadelige foretaksstrukturendringer verken fanges opp av foretakssammenslutningsreglene eller atferdsreglene.

\section{$4 \quad$ Fullfunksjonsvilkårets virkefelt vs. foretaksfusjoner og kontrollovertakelser}

\subsection{Introduksjon}

Spørsmålet er om fullfunksjonskravet også gjelder for at (enkelte) foretaksfusjoner eller kontrollovertakelser kvalifiserer til foretakssammenslutninger. Fusjonsforordningen artikkel 3 og konkurranseloven $\S 17$ er ikke entydige, da fellesforetak også kan opprettes ved fusjon og kontrollovertakelse av foretak. Det kan følgelig spørres om fullfunksjonsvilkåret også gjelder slike foretaksstrukturendringer. Alternativt gjelder vilkåret kun fellesforetaksopprettelser som tilføres begrensede aktiva (ikke «foretak») fra felleskontrollerende foretak eller tredjeparter.

EU-kommisjonens praktisering av fullfunksjonsvilkårets virkefelt har ikke vært konsistent, ${ }^{58}$ og Jurisdiksjonsmeddelelsen er ikke entydig. ${ }^{59}$ Konkurransetilsynet synes heller ikke å ha inntatt en konsekvent tilnærming, selv om vedtaksmaterialet er meget beskjedent. ${ }^{60}$ Det kan også variere om fellesforetaksetableringer over eksisterende foretak meldes som fusjon/kontrollerverv eller som opprettelse av fullfungerende fellesforetak.

EU-domstolen behandlet fullfunksjonsvilkårets virkefelt for hittil eneste gang i nevnte Austria Asphalt vs. Bundeskartellanwalt ${ }^{61}$ fra september 2017. I denne delen, og på bakgrunn av den foregående diskusjonen av fullfunksjonsvilkårets implikasjoner, diskuteres først EU-domstolens uttalelser og grunngiving og deretter rettstilstanden etter avgjørelsen.

\footnotetext{
57 Se bl.a. IV/32.732, IJsselcentrale (1991), IV/32.186, Gosme/Martell - DMP (1991), IV/32.737, Eirpage (1991), Commission Notice on restrictions directly related and necessary to concentrations, avsnitt 36, sak COMP/M.3099, Areva/Urenco/ETC JV, avsnitt 222, Draft Guidelines on the applicability of Article 101 of the Treaty on the Functioning of the European Union to horizontal co-operation agreements (2010), avsnitt 11.

${ }^{58}$ Se Lars-Peter Rudolf \& Bettina Leupold, Joint Ventures - the Relevance of the Full Functionality Criterion under the EU Merger Regulation: There Remains a Need for Clarification, Journal of European Competition Law \& Practice, 2012, 3(5), s. 439-451.

${ }^{59}$ Se Jurisdiksjonsmeddelelsen, avsnitt 91 og 92.

60 Sml. A1999-16, Wilh. Wilhelmsen og Walleniusrederierna og V2014-2, Altor Fund III / TryghedsGruppen -

ELIXIA Holding III /Health \& Fitness Nordic.

${ }^{61}$ Sak C-248/16, Austria Asphalt, ECLI:EU:C:2017:643.
} 


\subsection{EU-domstolen i Austria Asphalt vs. Bundeskartellanwalt}

I mai 2016 mottok EU-domstolen anmodning om en prejudisiell avgjørelse fra $\varnothing$ sterrikes Oberster Gerichtshof i tvist mellom selskapet Austria Asphalt GmbH («Austria Asphalt») og Bundeskartellanwalt (Østerrikes føderale kartellombud) om tolkningen av fusjonsforordningens foretakssammenslutningsbegrep.

Sakens utspring var et planlagt fellesforetak mellom Austria Asphalt (et selskap i Strabag-konsernet) og Teerag Asdag AG («Teerag») (et selskap i Porr-konsernet). Teerag eide asfaltblandeanlegget Mürzzuschlag. Anleggets produksjon gikk til Porr-konsernet. Austria Asphalt og Teerag ville opprette et felleskontrollert selskap som skulle overta Mürzzuschlag. Fellesforetaket ville ikke bli selvstendig fungerende ettersom størstedelen av produksjonen ville gå til Strabag- og Porr-konsernene.

Transaksjonen ble først meldt til Bundeswettbewerbsbehörde ( $\varnothing$ sterrikes føderale konkurransemyndighet). ${ }^{62}$ Bundeskartellanwalt brakte saken inn for Kartellgericht ( $\varnothing$ sterrikes konkurransedomstol). EU-kommisjonen hadde da angivelig informert Austria Asphalt om at transaksjonen tilsynelatende ikke utgjorde en foretakssammenslutning. ${ }^{63}$ Kartellgericht kom derimot til at etableringen av fellesforetaket var en foretakssammenslutning, og avviste videre behandling av saken. Implikasjonen var at transaksjonen likevel skulle meldes EU-kommisjonen.

Austria Asphalt anla deretter sak for Oberster Gerichtshof om avvisningsavgjørelsen og gjorde gjeldende at kun etablering av et fullfungerende fellesforetak utgjør en foretakssammenslutning. Oberster Gerichtshof anmodet EU-domstolen om en tolkningsavgjørelse. For EU-domstolen argumenterte EU-kommisjonen denne gang med at en transaksjon som beskrevet utgjør en foretakssammenslutning, selv om fellesforetaket ikke vil være selvstendig fungerende. Generaladvokat Kokott avga et forslag til avgjørelse i april 2017 og bemerket blant annet at «[i]t is extremely regrettable that, on such a fundamental and recurrent issue of competence, the Commission did not first commit to a clear and uniform approach and then apply it consistently». ${ }^{64}$

EU-domstolens resultat svarer tilsynelatende til generaladvokatens forslag. Slutningen var at det kun er tale om en foretakssammenslutning ved en endring fra enekontroll til felleskontroll over et foretak dersom fellesforetaket vil være fullfungerende. ${ }^{65}$

Etter å ha redegjort for fusjonsforordningens uklare ordlyd, påpekte EU-domstolen at forordningen ikke sondrer mellom nyopprettede fellesforetak og enekontrollerte foretak som blir felleskontrollert. ${ }^{66}$ EU-domstolen forklarte: "That lack of a distinction is entirely justified due to the fact that, although the creation of a joint venture must be assessed by the Commission as regards its effects on the structure of the market, the realisation of such effects depends on the actual emergence of a joint venture into the market, that is to say, of an undertaking performing on a lasting basis all the functions of an autonomous economic entity. ${ }^{67}$ Implikasjonen var at "Article 3 of the regulation

\footnotetext{
$62 \emptyset$ sterriksk fusjonskontrollrett har et videre anvendelsesområde enn foretakssammenslutningsbegrepet.

63 I et "comfort letter», se generaladvokat Kokotts forslag til avgjørelse sak C-248/16, Austria Asphalt, ECLI:EU:C:2017:322, avsnitt 14.

${ }^{64}$ Generaladvokat Kokotts forslag til avgjørelse sak C-248/16, Austria Asphalt, ECLI:EU:C:2017:322, avsnitt 22.

65 Sak C-248/16, Austria Asphalt, ECLI:EU:C:2017:643, avsnitt 35.

66 Ibid., avsnitt 21-23.

67 Ibid., avsnitt 24.
} 
therefore concerns joint ventures only in so far as their creation provokes a lasting effect on the structure of the market». ${ }^{68}$

Til argumentasjonen er det flere forhold å bemerke. Uttalelsene kan synes å sammenblande foretaksstrukturelle og markedsstrukturelle virkninger. Foretakssammenslutningsbegrepet gjelder imidlertid førstnevnte og er frikoblet fra sistnevnte. Foretaksstrukturelle virkninger, ved at separate foretak danner ett enkelt foretak, er uavhengige av om foretakene har overlappende, etterfølgende eller komplementær virksomhet av betydning for markedsstrukturen. Markedsstrukturelle virkninger er derimot avgjørende for inngrepsvurderingen. ${ }^{69}$ Det er heller ikke slik at markedsstrukturelle virkninger forutsetter inntreden av et selvstendig fungerende fellesforetak. Felleskontrolletableringer over tidligere enekontrollerte eller ikke-kontrollerte foretak kan medføre markedsstrukturelle endringer uavhengig av fellesforetakets fremtidige operasjonelle selvstendighet. Et eksempel er der fellesforetaket ikke lenger vil tilby varer eller tjenester til tredjeparter, men kun drive foretaksinterne støttefunksjoner. EU-domstolens argumentasjon fremstår dessuten generell og allmenn, ikke særskilt for enkelte felleskontrolletableringer.

Videre argumenterte EU-domstolen med at et motsatt tolkningsresultat vil innebære en ugrunnet forskjellsbehandling mellom nyopprettede foretak som kun utgjør foretakssammenslutninger dersom de vil være fullfungerende, og kontrollendringer over eksisterende foretak som utgjør foretakssammenslutninger uavhengig av fremtidig fullfunksjonsstatus. ${ }^{70}$ Fullfunksjonsvilkåret gjelder derfor "regardless of whether that undertaking, now jointly controlled, existed before the transaction $»{ }^{71}$ Til dette kan innvendes at EU-domstolens uttalelser snarere innebærer en ugrunnet likebehandling av foretaksstrukturendringer og nyetableringer og en ugrunnet forskjellsbehandling mellom ulike foretaksstrukturendringer der det formentlig kun for enkelte gjelder et fullfunksjonsvilkår. Fullfunksjonsvilkåret bør forbeholdes opprettelser av nye, felleskontrollerte foretak fordi varige kontrollendringer over eksisterende foretak innebærer foretaksstrukturelle endringer uavhengig av (felles-)foretakets eventuelle fremtidige operasjonelle autonomi. Ved nyopprettede fullfungerende fellesforetak er det derimot nærere tale om en foretaksstrukturell endring enn et atferdsmessig samarbeid.

EU-domstolen argumenterte også med hensynet til EU-konkurranserettens indre sammenheng. ${ }^{72} \mathrm{EU}$ domstolen viste blant annet til at fusjonsforordningen artikkel 21 (1) innebærer at forordning 1/2003 om håndheving av atferdsreglene ikke er anvendelig på foretakssammenslutninger. Slutningen var at: "The Commission's interpretation (...), according to which a change in the control of an undertaking which, previously exclusive, becomes joint is covered by the concept of concentration even if the undertaking does not perform on a lasting basis all the functions of an autonomous economic entity is not, therefore, consistent with Article 21(1) thereof. Such an interpretation would effectively extend the scope of the preventative control laid down in that regulation to transactions which are not capable of having an effect on the structure of the market in question and would, at the same time, limit the scope of Regulation No 1/2003, which would then no longer be applicable to such transactions, even

\footnotetext{
68 Ibid., avsnitt 25.

69 Jf. fusjonsforordningen artikkel 2. Se også sak C-633/16, Ernst \& Young, ECLI:EU:C:2018:371, avsnitt 50-51.

70 Sak C-248/16, Austria Asphalt, ECLI:EU:C:2017:643, avsnitt 27.

71 lbid., avsnitt 28.

72 Ibid., avsnitt 29.
} 
though they may lead to coordination between undertakings within the meaning of Article 101 TFEU. ${ }^{73}$

Også til dette kan innvendes at foretakssammenslutningsbegrepet og forhåndskontrollregimet ikke er begrenset til konsolideringer med markedsstrukturelle virkninger. Markedsvirkninger er ikke engang relevant etter foretakssammenslutningsdefinisjonen. Som nevnt er det heller ikke slik at endringer fra enekontroll til felleskontroll over eksisterende foretak ikke kan ha markedsstrukturelle virkninger der fellesforetaket ikke vil være operasjonelt autonomt. Dersom et foretak med $50 \%$ markedsandel erverver negativ kontroll over et foretak med $50 \%$ markedsandel, vil markedsstrukturelle virkninger kunne inntre uavhengig av om fellesforetaket settes opp med indre ressurser og ytre relasjoner til å kvalifisere som fullfungerende. Dersom en skulle legge til grunn at en foretaksstrukturendring uten fullfunksjonskvalifikasjon ikke kan ha markedsvirkninger, er det videre uforståelig hvordan konkurransen da likevel kan hindres under TEUV artikkel 101. Og uansett kommer forordning 1/2003 til anvendelse på fellesforetaksopprettelser uten EU-dimensjon som har til formål eller virkning å samordne uavhengige foretaks konkurranseatferd, det vil si mellom felleskontrollerende foretak. ${ }^{74}$

Før fullfunksjonsvilkårets virkefelt etter Austria Asphalt vs. Bundeskartellanwalt skal diskuteres nærmere, kan det bemerkes at EU-domstolens avgjørelsesslutning har en paradoksal side. En sterk konsolidering av selvstendige foretak synes å bringe foretaksstrukturendringen utenfor regelverket om foretaksstrukturendringer. En løsere konsolidering, der fellesforetaket tilkjennes kvalifisert operasjonell autonomi, synes derimot å bringe kontrollendringen inn under reglene om forhåndskontroll med foretakssammenslutninger.

\subsection{Fullfunksjonsvilkårets virkefelt etter Austria Asphalt vs. Bundeskartellanwalt}

Det er på det rene at foretakssammenslutningsdefinisjonen oppstiller et fullfunksjonsvilkår for fellesforetakopprettelser som ikke kommer i stand ved foretaksfusjon eller kontrollerverv over eksisterende foretak. EU-domstolens avgjørelse endrer ikke dette utgangspunktet. Avgjørelsen gir heller ikke en entydig avklaring av vilkårets virkefelt. EU-domstolens formuleringer tilsier en utvidelse av virkefeltet, men det er likevel ikke klart hvor ekspansivt grensen for virkeområdet da skal trekkes.

Et moderat alternativ er at avgjørelsen innebærer at fullfunksjonsvilkåret også gjelder endringer fra enekontroll til felleskontroll over eksisterende foretak, der enekontrollerende foretak forblir felleskontrollerende foretak. ${ }^{75}$ En forutsetning om at et tidligere enekontrollerende foretak forblir et felleskontrollerende foretak, må eventuelt forankres i foreleggelsesspørsmålet. Etter dette alternativet vil det nok også måtte oppstilles et fullfunksjonsvilkår ved fellesforetaksetableringer som kommer i stand ved fusjon av enekontrollerte foretak der de enekontrollerende foretakene beholder felles kontroll over den fusjonerte virksomheten.

Et noe videre alternativ er at fullfunksjonsvilkåret også gjelder ved endringer til felleskontroll over tredjepartskontrollerte foretak. Et slikt tolkningsalternativ fremstår i samsvar med EU-domstolens avgjørelsesslutning. Det er dessuten vanskelig å se grunner til at fullfunksjonsvilkåret skulle gjelde der

\footnotetext{
${ }^{73}$ Sak C-248/16, Austria Asphalt, ECLI:EU:C:2017:643, avsnitt 34.

74 Tilsvarende kan avsnitt 34 vanskelig forstås dithen at kontrollerende og kontrollerte foretak er separate foretak under atferdsreglene.

${ }^{75}$ I den retning, Lars-Peter Rudolf, Austria Asphalt: Only Full-Function Joint Ventures Subject to Review Under the EUMR, Journal of European Competition Law \& Practice, 2018, Vol. 9 No. 2, s. 107-109, på s. 109.
} 
et tidligere enekontrollerende foretak forblir et felleskontrollerende foretak, men ikke der fellesforetaket etableres av et tidligere tredjepartskontrollert foretak.

Et enda videre alternativ er at fullfunksjonsvilkåret anses å gjelde ved alle fellesforetaksetableringer. ${ }^{76}$ Dette alternativet er riktignok videre enn EU-domstolens avgjørelsesslutning. Det er likevel ingen ting i EU-domstolens grunngiving som forklarer hvorfor fullfunksjonsvilkårets virkefelt skulle gjelde enkelte fellesforetaksetableringer, men ikke andre.

Det mest ekspansive alternativet er å anse avgjørelsen for å innebære at det gjelder et fullfunksjonsvilkår ved alle foretaksstrukturendringer under foretakssammenslutningsbegrepet. Det vil si at fullfunksjonsvilkåret også gjelder ved alle typer kontrollerverv og foretaksfusjoner. Gitt at det gjelder et fullfunksjonsvilkår ved enkelte kontrollendringer over eksisterende foretak, skulle vel vilkåret gjelde ved alle varige foretaksstrukturendringer. EU-domstolens grunngiving er dessuten dels generell og ikke begrenset til enkelte felleskontrolletableringer. Foreleggelsesspørsmålet og avgjørelsesslutningen er imidlertid rettet mot fellesforetaksetableringer, noe som i det minste tilsier at dette ytterliggående alternativet ikke bør legges til grunn.

Dersom EU-domstolens avgjørelse anses å utvide fullfunksjonsvilkårets virkefelt, er det følgelig uklart hvor ekspansivt den skal forstås, og hvor grensen for virkeområdet trekkes.

Selv om enkeltformuleringer og avgjørelsesslutningen i Austria Asphalt vs. Bundeskartellanwalt tilsier en ekspansjon av fullfunksjonsvilkårets virkefelt, er det argumenter og holdepunkter også for en fortsatt restriktiv fortolkning. Det restriktive alternativet innebærer at det kun gjelder et fullfunksjonsvilkår ved opprettelser av fellesforetak som ikke kommer i stand ved foretaksfusjoner eller kontrollovertakelser av eksisterende foretak. ${ }^{77}$

EU-domstolens grunngiving var blant annet forankret $\mathrm{i}$ hensynet til fusjonsforordningens og konkurranseregelverkets oppbygging og indre sammenheng. Slike hensyn begrunner derimot snarere en restriktiv tolkning av fullfunksjonskravets virkefelt for ikke å skape en konkurranserettslig «blindsone» der konkurranseskadelige foretaksstrukturendringer verken kan hindres av foretakssammenslutningsreglene eller atferdsreglene. ${ }^{78}$ For ${ }^{8}$ vrig viser foretakssammenslutningsbegrepet til foretaksstrukturendringer der tidligere separate foretak danner ett enkelt foretak. Etableringen av en ny økonomisk enhet ved fusjon eller kontrollerverv skjer uavhengig av om det for fremtiden opprettes en på varig grunnlag fullfungerende delvirksomhet. Fusjonsforordningens fortale indikerer dertil at inkluderingen av fullfungerende fellesforetak $\mathrm{i}$ foretakssammenslutningsbegrepet snarere tilsiktet å utvide fusjonsforordningens kvalitative anvendelsesområde enn å innskrenke fusjons- og kontrollervervsalternativene. ${ }^{79}$ Motargumentet er at EU-domstolen synes å anvise et fullfunksjonsvilkår knyttet til det planlagt opprettede fellesforetaket ved en endring til felleskontroll over et foretak. ${ }^{80}$

\footnotetext{
${ }^{76}$ Se Lars-Peter Rudolf, Austria Asphalt: Only Full-Function Joint Ventures Subject to Review Under the EUMR, Journal of European Competition Law \& Practice, 2018, Vol. 9 No. 2, s. 107-109, på s. 109.

77 I den retning, Anders Ryssdal og Håkon Cosma Størdal, Norsk Konkurranserett, Bind II - Fusjonskontroll, Universitetsforlaget 2018, s. 61.

${ }^{78}$ Se generaladvokat Kokotts forslag i sak C-248/16, Austria Asphalt, ECLI:EU:C:2017:322, avsnitt 46, som referer til at EU-kommisjonen under høringen løftet frem risikoen for en "gap in the effective enforcement»..

${ }^{79}$ Fusjonsforordningens fortale, avsnitt 20.

${ }^{80}$ Se også avsnitt 28.
} 
Når det restriktive tolkningsalternativet ikke kan avvises etter tolkningsavgjørelsen, skyldes det også indikasjoner på at EU-domstolen ikke har skilt klart mellom foretaksbegrepet og fullfunksjonsvilkåret. Fusjons- og kontrollervervsalternativene innebærer at minst to eksisterende "foretak» konsolideres til én økonomisk enhet. Følgelig må også kontrollendringsobjektet kvalifisere til et «foretak» forut for kontrollendringen. Fullfunksjonsvilkåret er derimot ikke knyttet til et kontrollendringsobjekt, men til et forutsatt opprettet fellesforetaks varige og løpende operasjonelle autonomi. Formuleringer i EUdomstolens tolkningsavgjørelse knyttet riktignok fullfunksjonsvilkåret til et planlagt fellesforetak. Av EU-domstolens saksfremstilling fremgår likevel at produksjonen til kontrollendringsobjektet, asfaltblandeanlegget Mürzzuschlag, gikk til foretakskonsernet som det allerede var en del av. Det var følgelig ikke åpenbart at objektet for kontrollendringen kvalifiserte til et «foretak», selv om det synes forutsatt. Uten en slik forutsetning blir EU-domstolens grunngiving mer forståelig. Uttalelser om at strukturelle endringer er betinget av fullfunksjonsvilkåret, gir blant annet mer mening dersom det ikke var tale om en kontrollendring over et eksisterende foretak.

Generaladvokat Kokotts avgjørelsesforslag kan underbygge en hypotese om sammenblanding av foretaksbegrepet og fullfunksjonsvilkåret. Generaladvokaten fremhevet at transaksjonsgjenstanden, asfaltblandeanlegget Mürzzuschlag, ikke utgjorde en fullfungerende virksomhet før den planlagte fellesforetaksopprettelsen. ${ }^{81}$ Mens EU-domstolen presiserte tolkningsspørsmålet ved å knytte fullfunksjonsvilkåret til det planlagte fellesforetaket ${ }^{82}$, formulerte generaladvokaten et spørsmål der vilkåret ble knyttet til objektet for kontrollendringen. ${ }^{83}$ I den videre drøftelsen skilte generaladvokaten likevel ikke konsekvent mellom betydningen av om fellesforetaket ville bli fullfungerende, ${ }^{84}$ og betydningen av om transaksjonsobjektet utgjorde en fullfungerende virksomhet. ${ }^{85}$ Generaladvokaten synes dessuten å forveksle foretakstermen som angivelse av kontrollendringsobjekt under kontrollervervsalternativet og fullfunksjonstermen som krav til fellesforetak under fullfunksjonsalternativet.

Generaladvokaten argumenterte likevel for et sammenfallende foretaks- og fullfunksjonsbegrep under kontrollervervsalternativet. ${ }^{86}$ Det er potensielt betydningsfullt fordi det kan klargjøre kontrollendringsobjektets nedre grense under fusjons- og kontrollervervsalternativet. Argumentasjonen tydeliggjør at et foretaks kontrollerverv av begrensede aktiva, så som kundebaser ${ }^{87}$, immaterielle rettigheter ${ }^{88}$, næringseiendom ${ }^{89}$, butikklokaler ${ }^{90}$ mv., ikke utgjør noen foretakssammenslutning, med mindre kontrollendringsobjektet kvalifiserer til et («fullfungerende») «foretak». Videre vil heller ikke «outsourcing-transaksjoner» utgjøre noen foretakssammenslutning $i$ form av et alminnelig kontrollerverv, der kontrollendringsobjektet ikke kvalifiserer til et («fullfungerende») «foretak». ${ }^{91}$ Det kan være tilfellet der objektet for outsourcing-transaksjonen består av begrensede aktiva uten tilhørende tilstrekkelige indre, operasjonelle og uavhengige

\footnotetext{
${ }^{81}$ Generaladvokat Kokotts forslag i sak C-248/16, Austria Asphalt, ECLI:EU:C:2017:322, avsnitt 2 og 4.

82 Sak C-248/16, Austria Asphalt, ECLI:EU:C:2017:643, avsnitt 14.

${ }^{83}$ Generaladvokat Kokotts forslag i sak C-248/16, Austria Asphalt, ECLI:EU:C:2017:322, avsnitt 3.

${ }^{84}$ Ibid., avsnitt 19, 20 og 48.

85 Ibid., avsnitt 2, 4 og 21.

${ }^{86}$ Ibid., avsnitt 33. I den retning også avsnitt 45.

$87 \mathrm{Sml}$. Jurisdiksjonsmeddelelsen, avsnitt 24.

88 Ibid., avsnitt 24.

${ }^{89} \mathrm{Sml}$. Konkurransetilsynets veiledning om næringseiendom, 7. september 2005.

$90 \mathrm{Sml}$. Konkurransetilsynets vedtak V2014-3, Norgesgruppen.

${ }^{91} \mathrm{Sml}$. Jurisdiksjonsmeddelelsen, avsnitt 25-27.
} 
foretaksfunksjoner. Det kan også være tilfellet der kontrollendringsobjektet ikke har hatt tilstrekkelig ytre autonom markedstilstedeværelse og ikke har tilbudt varer eller tjenester til tredjeparter $i$ et marked. Felles for eksemplene er at EU-kommisjonen og Konkurransetilsynet har tillagt foretakssammenslutningsbegrepet st $\varnothing$ rre rekkevidde enn hva foretaksbegrepet og generaladvokatens presisering av et sammenfallende fullfunksjonsbegrep tilsier.

Det er følgelig indikasjoner på at transaksjonsobjektet i foreleggelsessaken kan forklare EUdomstolens tolkningsavgjørelse. Til tross for at asfaltblandeanlegget Mürzzuschlags produksjon gikk til foretakskonsernet som det opprinnelig var en del av, synes foreleggelsesspørsmålet og EUdomstolens avgjørelse å forutsette at anlegget kvalifiserte til et «foretak». Generaladvokaten synes å behandle dels betydningen av om transaksjonsobjektet var fullfungerende før kontrollendringen, og dels betydningen av om det planlagte fellesforetaket ville bli fullfungerende. I EU-domstolens påfølgende avgjørelse fremstår fullfunksjonsvilkåret som et tilleggskrav for fellesforetak som kommer i stand ved foretaksstrukturendringer over eksisterende "foretak», etter en lite meningsfull grunngiving.

Fullfunksjonsvilkårets virkefelt har, som vist, implikasjoner for samvirket mellom konkurranserettens regelsett. En utvidelse av virkefeltet innskrenker foretakssammenslutningsbegrepet og derved gjenstanden for konkurranserettens forhåndskontrollregelverk. Selv om konkurransemyndighetenes atferdsrettslige håndhevingskompetanse utvides tilsvarende, kan ikke de materielle atferdsforbudene fullgodt motvirke konkurranseskadelige foretaksstrukturendringer som faller utenfor foretakssammenslutningsbegrepet. Dess mer ekspansivt grensen for fullfunksjonsvilkårets virkefelt trekkes, dess mer utvides den konkurranserettslige «blindsonen». Konsistent med EU-domstolens systemorienterte grunngiving er det følgelig vektige argumenter også for å fastholde en restriktiv fortolkning, der fullfunksjonsvilkårets virkefelt begrenses til fellesforetakopprettelser som ikke kommer i stand ved foretaksfusjon eller kontrollovertakelse av eksisterende «foretak». 